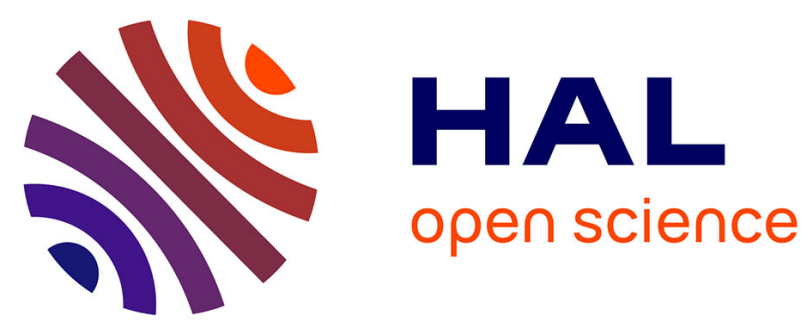

\title{
Simulating the spatial variability of nitrous oxide emission from cropped soils at the within-field scale using the NOE model
}

Agnès Grossel, Bernard Nicoullaud, Hocine Bourennane, Pierre Rochette, Christophe Guimbaud, M. Chartier, Valéry Catoire, C. Hénault

\section{To cite this version:}

Agnès Grossel, Bernard Nicoullaud, Hocine Bourennane, Pierre Rochette, Christophe Guimbaud, et al.. Simulating the spatial variability of nitrous oxide emission from cropped soils at the within-field scale using the NOE model. Ecological Modelling, 2014, 288, pp.155-165. 10.1016/j.ecolmodel.2014.06.007 . insu-01064719

\section{HAL Id: insu-01064719 \\ https://hal-insu.archives-ouvertes.fr/insu-01064719}

Submitted on 18 Jan 2016

HAL is a multi-disciplinary open access archive for the deposit and dissemination of scientific research documents, whether they are published or not. The documents may come from teaching and research institutions in France or abroad, or from public or private research centers.
L'archive ouverte pluridisciplinaire HAL, est destinée au dépôt et à la diffusion de documents scientifiques de niveau recherche, publiés ou non, émanant des établissements d'enseignement et de recherche français ou étrangers, des laboratoires publics ou privés.

\section{(1) (1) $\$$}

Distributed under a Creative Commons Attribution - NonCommercial - NoDerivatives 44.0 


\title{
Simulating the spatial variability of nitrous oxide emission from cropped soils at the within-field scale using the NOE model
}

\author{
A. Grossel ${ }^{a *}$, B. Nicoullaud ${ }^{a}$, H. Bourennane ${ }^{a}$, P. Rochette ${ }^{b}$, C. Guimbaud ${ }^{c}$, M. Chartier ${ }^{c}$, V. \\ Catoire $^{c}$, C. Hénault ${ }^{\mathrm{a}}$
}

a. INRA, UR 0272 Science du sol, Centre de recherche Val de Loire, CS 40001 Ardon, 45075 Orléans cedex 2, France.

b. Agriculture and Agri-Food Canada, 2560 Hochelaga Blvd, Québec, QC, G1V 2J3, Canada;

c. Laboratoire de Physique et Chimie de l'Environnement et de l'Espace (LPC2E), UMR 7328 CNRS-Université d'Orléans, 3A Avenue de la Recherche Scientifique, 45071 Orléans Cedex 2, France

* Corresponding author. Phone: +33- 238418048

E-mail address: agnes.grossel@orleans.inra.fr

\section{Abstract.}

Estimating total $\mathrm{N}_{2} \mathrm{O}$ emission from agricultural soils is associated with considerable uncertainty due to the very large spatial variability of the fluxes. Thus characterizing the range of variations is of great interest. Modelling $\mathrm{N}_{2} \mathrm{O}$ fluxes remains challenging, especially at the within-field scale. The aim of this study was to test the ability of a simple processbased model, NOE (Nitrous Oxide Emission), to simulate $\mathrm{N}_{2} \mathrm{O}$ at scales finer than the field. Six field studies including 30 to 49 measurements of chamber $\mathrm{N}_{2} \mathrm{O}$ fluxes and ancillary variables were conducted in a barley/wheat field on hydromorphous soils. Three studies were made on surfaces of $\sim 10 \mathrm{~m}^{2}$ (defined as the local scale), and three studies along a 150$\mathrm{m}$ transect (defined as the transect scale). First, the model was tested deterministically for predicting the flux spatial patterns, i.e., to try to reproduce the high flux points. Then the denitrification part of the model was tested stochastically for simulating the flux distributions by randomly generating input variables from the measured frequency distributions (Monte Carlo simulation). Measured fluxes were comprised between 0 and $1.5 \mathrm{mg} \mathrm{N} \mathrm{h}^{-1} \mathrm{~m}^{-2}$. The deterministic prediction of spatial patterns provided a good match with measurements in 1 of the 6 studied cases, in a transect study. Denitrification was assessed to be the main source of $\mathrm{N}_{2} \mathrm{O}$ in 5 of the 6 cases and the model satisfactorily simulated frequency distributions in 4 
cases out of 5,2 at the local scale and 2 at the transect scale. Thus this study suggests that simple process-based models such as NOE, combined to Monte Carlo methods, can be used to improve simulation of the skewed frequency distributions of $\mathrm{N}_{2} \mathrm{O}$ fluxes and provide valuable information about the range of spatial variations in $\mathrm{N}_{2} \mathrm{O}$ fluxes.

Keywords: greenhouse gas, soil fluxes, spatial variability, frequency distribution, Monte Carlo simulation.

\section{Introduction}

Fluxes of the greenhouse gas nitrous oxide $\left(\mathrm{N}_{2} \mathrm{O}\right)$ from agricultural soils exhibit considerable spatial variability at all scales (Ambus and Christensen, 1994; Stehfest and Bouwman, 2006; van den Heuvel et al., 2009). At fine scale such as plot or within-plot scales $\left(\sim 10 \mathrm{~m}^{2}\right.$ to $\sim 1000 \mathrm{~m}^{2}$ ), $\mathrm{N}_{2} \mathrm{O}$ fluxes are characterized by the frequent occurrence of extreme values or "hotspots" (Parkin, 1987; van den Heuvel et al., 2009) which account for a significant part of the plot fluxes. $\mathrm{N}_{2} \mathrm{O}$ is produced by microbial processes in soils at the microscale (Parkin 1987 ) and the spatial variability results from these biological processes at local scale and from physicochemical processes acting at larger scale (region), due for example to climate, soil use and cropping practices. Studies have been conducted to represent the spatial variability at the region or country scale (Gabrielle et al., 2006, Lugato et al., 2010) with comprehensive agro-ecosystem models involving a large number of parameters requiring calibration (Lamers et al., 2007). Conversely the local scale variability and the hotspot occurrences have been much less accounted for into models (Groffman et al., 2009) and this remains a key challenge due to the difficulty to get high resolution spatial values of $\mathrm{N}_{2} \mathrm{O}$ flux drivers.

An explicit spatial determination of high flux areas at within field scale could be useful for fine scale management practices (precision agriculture). It could also help improving the modelling at larger scales. Regional or landscape-scale variability of $\mathrm{N}_{2} \mathrm{O}$ fluxes can include a significant part of the fine scale variability and thus the accuracy of model prediction at an 
aggregated scale can depend on the quality of the simulations of variability at a finer scale (Pringle et al., 2008). Therefore it is very important to model correctly the fine-scale variability of $\mathrm{N}_{2} \mathrm{O}$ fluxes.

There have been numerous spatial studies on the spatial variability of $\mathrm{N}_{2} \mathrm{O}$ fluxes at fine scale based on measurements (e.g. Ambus and Christensen, 1994; Turner et al., 2008; Nishina et al., 2009) while to our knowledge few studies have been carried out to predict this spatial pattern at fine scale. Stacey et al. (2006) used regression kriging to improve process modelling based on flux measurements made on soil cores taken during a spatial campaign along a $1-\mathrm{km}$ long transect and incubated in laboratory. The flux prediction was based on multiplicative models with rate limiting dimensionless functions of soil variables, which provide a simple tool for predicting $\mathrm{N}_{2} \mathrm{O}$ fluxes (e.g. Hashimoto et al., 2011). The present study intends to test modelling at a finer scale (within-field scale), and to replicate spatial campaigns to assess the ability of model to account also for the temporal variations of spatial patterns.

Spatial studies based on measurements have led to the conclusion that "soil variables measured in bulk samples do not represent the integrated effect of the interaction of factors which control $\mathrm{N}_{2} \mathrm{O}$ production at the soil microsites" (Velthof et al., 1996). This means that the deterministic prediction of local $\mathrm{N}_{2} \mathrm{O}$ fluxes from these soil variables may in fact be very uncertain. Spatial variability of a soil variable can also be characterized by the frequency distribution. The latter gives information about the entire spectre of variation for a given variable instead of a specific value. $\mathrm{N}_{2} \mathrm{O}$ flux distributions measured during spatial campaigns are generally skewed due to the patchy spatial pattern of $\mathrm{N}_{2} \mathrm{O}$ fluxes produced by hotspots (Parkin 1987) and spatial studies have shown that the $\mathrm{N}_{2} \mathrm{O}$ fluxes exhibit lognormal distribution (e.g. Turner et al., 2008; Konda et al., 2008). For such soil variables, using average of a few replicated measurements would provide a biased estimation of the mean value. As the flux distributions are varying over time, it is important to simulate the range of distributions associated with fluxes (Yates et al., 2006). Denitrification rate, which is 
important in explaining the $\mathrm{N}_{2} \mathrm{O}$ fluxes, is an example of such soil variable exhibiting lognormal distributions. For the skewed distributions of the denitrification rate, Parkin and Robinson (1989) presented one study in which a stochastic simulation using a multiplicative model was preferable to a deterministic simulation. A similar approach may thus provide an efficient way to estimate the variability of $\mathrm{N}_{2} \mathrm{O}$ fluxes at fine scales.

The objectives of the present study were to measure the spatial variability of soil $\mathrm{N}_{2} \mathrm{O}$ fluxes at the within-field scale in a cropped field and to assess the capacity of a process-based multiplicative model, NOE (Nitrous Oxide Emission, Hénault et al., 2005), to predict this spatial variability. To deal with the objectives above, six measurement campaigns were carried out at two scales finer than the field $\left(\sim 10 \mathrm{~m}^{2}\right.$ and a $150 \mathrm{~m} \times 12 \mathrm{~m}$ transect $)$ and the model was tested for 2 aims: (1) the ability to predict a single value of flux for a given location (deterministic prediction), and (2) the simulation of the flux distributions (stochastic simulation).

\section{2. Material and methods}

\subsection{Experimental site}

The study was carried out in a field on a privately owned farm in the Loir river valley, about $120 \mathrm{~km}$ south-west of Paris, France. This field is situated on poorly drained loamy soils similar to Gleyic Albeluvisol (IUSS-WRB, 2006). Previous $\mathrm{N}_{2} \mathrm{O}$ studies in this area clearly suggest that soil $\mathrm{N}_{2} \mathrm{O}$ fluxes are mainly due to the denitrification process (Hénault et al., 2005). The present study was conducted during the spring of 2011 and 2012, after fertilizer applications, because large $\mathrm{N}_{2} \mathrm{O}$ fluxes had already been measured in this region during the same period in previous years (Gu et al., 2011). The field had previously been under fallow, and was cropped since 2009. The crop rotation in 2010-2012 was winter wheat - winter barley - winter wheat. Tillage, the incorporation of straw residues, and sowing with winter barley took place on 3 October 2010. Nitrogen fertilizers were surface-applied on 17 February 2011 (65 kg N ha-1 ammonium nitrate pellets) and on 18 March 2011 (75 kg N ha-1 urea-ammonium nitrate solution). The crop was harvested on 10 July 2011 . The next tillage, 
113 incorporation of straw residues and sowing took place on 8 November 2011 and fertilizers were applied on 27 February 2012 (75 kg N ha ${ }^{-1}$ ammonium nitrate pellets) and 17 March 2012 (100 kg N ha ${ }^{-1}$ urea ammonium nitrate solution).

\subsection{Quick sampling methodology}

$\mathrm{N}_{2} \mathrm{O}$ fluxes were measured by coupling an infrared quantum cascade laser (QCL) spectrometer to a "fast box". This fast box is a mobile chamber, that does not require insertion in the soil, and that provides a rapid estimation of the fluxes when combined with an on-line analysis of gas concentration (Hensen et al., 2006; Flechard et al., 2007). The analyser was a laboratory-built instrument (known as SPIRIT) designed for the laser-based measurement of $\mathrm{N}_{2} \mathrm{O}$ and $\mathrm{CH}_{4}$ in the $7.9 \mu \mathrm{m}$ spectral range (Guimbaud et al., 2011, Gogo et al., 2011). This instrument has a special optical multipass cell (Robert, 2007) and is especially designed to work in the field. Its sensitivity at $0.7 \mathrm{~Hz}$ is less than $1 \mathrm{ppb}$ for $\mathrm{N}_{2} \mathrm{O}$.

The edges of the fast box are $7 \mathrm{~cm}$ in width with 4-cm high soft foam. The sensitivity and online response of the $\mathrm{N}_{2} \mathrm{O}$ analysis make it possible to check that a good seal is obtained when the fast box is pressed on to the soil surface. The fast box is a $35 \times 35 \mathrm{~cm}$ opaque PVC frame (18 $L$ whole volume) and is used as a non-steady state closed chamber. Air is mixed with a low voltage fan to prevent air stratification in the chamber during the measurement. The accumulation time was typically $6 \mathrm{~min}$, which is short enough to preclude any perturbation of fluxes due to an artificial temperature increase. Fluxes were calculated from the concentration increase inside the headspace, according to the HMR model (Pedersen et al., 2010), which provides a generalization of the exponential function of the model proposed by Hutchinson and Mosier (1981).

The main consideration when using a fast box is the possibility of poor sealing resulting in erroneous flux estimation. Sealing of the fast box could depend on the soil surface characteristics. A preliminary test was therefore conducted on-site to compare measurements obtained using a static chamber, with the frames inserted to $10 \mathrm{~cm}$ depth, 
and the fast box. The soil surface was quite smooth during the growing season and the fast box was shown to provide reliable measurements (see supplementary material).

\section{Measurement campaigns:}

Campaigns were carried out at 2 scales: 3 times on square areas of about $10 \mathrm{~m}^{2}$ (hereafter designated "S" campaigns and considered as "local scale") and 3 times on a transect 150-m in length down the main slope of the field (hereafter referred to as "T" campaigns). In total in 6 campaigns were conducted over 2 years to cover different climatic conditions.

The three $\mathbf{S}$ campaigns were designed to provide an almost complete coverage of the $\sim 10 \mathrm{~m}^{2}$ areas and to precisely determine the frequency distributions of the flux and soil variables. Measurements were done on 01/04/2011 (S1), 14/03/2012 (S2) and 28/03/2012 (S3) on different 10- $\mathrm{m}^{2}$ plots (Fig. 1). Fluxes were measured using $6 \times 8$ adjacent chamber deployments for S1 (covering a $2.56 \times 3.36-\mathrm{m}$ surface) and at $7 \times 7$ adjacent points for S2 and S3 (covering a $2.94 \times 2.94-\mathrm{m}$ surface). The fast box was carefully placed to ensure that the edges overlapped, i.e. the foam edge of the left side was placed exactly where the right edge had been placed during the previous flux measurement. Fluxes were never measured at a point where the box edge had been squeezed, so as to avoid possible effects of soil disturbance. This measuring technique made it possible to sample a large proportion $(70 \%)$ of the whole surface area. Two locations on the footslope and one on the shoulder were sampled (Fig. 1).

The three $\mathbf{T}$ campaigns were carried out along a 150-m transect on 24/03/2011 (T1), 08/03/2012 (T2) and 21/03/2012 (T3). The transects were oriented along the main slope with a grid of 7 transversal lines (12-m long) with 4 replicate points (spaced 3, 6 and 3-m) and two extra-points (Fig. 1). The lines were placed 25-m apart perpendicular to the tractor wheel tracks. The exact same positions as T1 (2011), measured with a GPS system, were used in T2 (2012), then all points were moved $1 \mathrm{~m}$ downward in the footslope direction for T3 because soil samples had been taken from the previously sampled sites during T2. 
165 The sampling duration of a campaign was typically $6 \mathrm{~h}$, from 10:30 to 16:00 (local time), so 34 points were sampled twice, at the beginning and end of the experiment, to check that temporal variation of the fluxes were in any case much smaller than spatial variations.

\subsection{Soil variables}

Two sets of ancillary variables were measured during or just after the spatial campaigns. Firstly, the soil properties were measured by taking single soil samples from the $0-25-\mathrm{cm}$ layer (corresponding to tillage depth) at each individual point on the transect, shortly after the T1 campaign. The samples were dried at room temperature, crushed and sieved to pass through a 2-mm mesh, and analysed for soil organic carbon and total $\mathrm{N}$ contents (dry combustion at $\left.1000^{\circ} \mathrm{C}\right)$, soil texture (pipette method), and $\mathrm{pH}(1: 5$ soil:water ratio, $\mathrm{v} / \mathrm{v})$.

Secondly, the input variables for the NOE model (see subsection 2.4) were measured at each point inside the surface area sampled with the fast box, just after the flux measurement. This was repeated for each spatial sampling campaign, at both scales. Soil temperature at 10-cm depth was measured using a thermocouple (Type K, TC Direct, UK) inserted directly in the soil. Several soil samples were collected from the $0-25-\mathrm{cm}$ soil layer at each flux measurement point. The first sample was used to measure gravimetric water content (GWC) and a composite of three soil replicates was prepared to determine mineral $\mathrm{N}$ contents. Fresh soils were extracted with $\mathrm{KCl}$ solution $(0.5 \mathrm{M})$ and $\mathrm{NH}_{4}{ }^{+}$and $\mathrm{NO}_{3}{ }^{-}$contents were determined using an automated discrete photometric analyzer (Aquakem 600, Thermo Fisher Scientific Inc., USA). Due to technical constraints, mineral nitrogen could only be measured at 8 points for S1 (4 zones of large flux and 4 of small flux).

Several bulk core replicates were taken to measure soil bulk density $(B D)$. Samples were collected using a fixed-volume cylinder $\left(500 \mathrm{~cm}^{3}\right)$ and then dried at $105^{\circ} \mathrm{C}$ for $48 \mathrm{~h}$. In 2011 , 56 replicates were sampled along the transect (T1) and 15 replicates were taken at the footslope position (S1). In 2012, 15 replicates were taken at the top and bottom positions. The mean $B D$ values for each sampling campaign were used to convert the GWC to Water- 
191 Filled Pore Space (WFPS), using a soil particle density of $2.65 \mathrm{~g} \mathrm{~cm}^{-3}$ (Gu et al., 2011): $W F P S=G W C \cdot B D /(1-B D / 2.65)$.

\subsection{Data analysis and modelling}

194

195

196

197

\section{Statistical analysis:}

The measurements were analyzed to characterize the spatial variability and to detect possible linear links between the variables. Normality tests were conducted on the direct data and the log-transformed data (Shapiro-Wilk, $5 \%$ level) because soil variables and $\mathrm{N}_{2} \mathrm{O}$ fluxes are known to often exhibit lognormal distributions (Turner et al., 2008). If the distribution was considered as lognormal, the maximum likelihood method was applied to calculate the mean and standard deviation, which may differ considerably from the method of moments, and gives better results if the number of samples is sufficiently large (Parkin et al., 1988; Mathieu et al., 2006). The difference between the flux levels in each campaign was calculated by Mann-Whitney test at a significance level of $5 \%$. Correlations between fluxes and soil variables were checked from the Pearson correlations.

\section{Model:}

$\mathrm{N}_{2} \mathrm{O}$ production in soils is mainly due to two microbial processes: denitrification, the reduction of nitrate $\left(\mathrm{NO}_{3}{ }^{-}\right)$to $\mathrm{N}_{2} \mathrm{O}$ and $\mathrm{N}_{2}$, and nitrification, the oxidation of $\mathrm{NH}_{4}{ }^{+}$to nitrite $\left(\mathrm{NO}_{2}{ }^{-}\right)$and $\mathrm{NO}_{3}{ }^{-}$(Skiba and Smith, 2000). The NOE model (Hénault et al., 2005) had already been tested on several sites, including sites of similar soil types (Gu et al., 2014) but not to study the spatial variability at within-field scale. In this model, $\mathrm{N}_{2} \mathrm{O}$ fluxes are predicted as a product of empirical functions (Hénault et al., 2005; see appendix for a complete description of functions). Two thresholds of WFPS are assumed (cf Fig. 2): $W_{1}$, the minimum WFPS at which denitrification can take place, and $W_{2}$, the maximum threshold at which nitrification can take place. $W_{2}$ was taken at 0.8 (Henault et al., 2005) and $W_{1}$ at 0.689 (Lehuger et al., 2009; Gu et al., 2014). Above $W_{1}$, denitrification is assumed to further reduce $\mathrm{N}_{2} \mathrm{O}$ at a fixed rate. The $r$ parameter is the fraction (between 0 and 1) of denitrification released as $\mathrm{N}_{2} \mathrm{O}$ and thus 
217 characterizes the capacity of the soil to reduce $\mathrm{N}_{2} \mathrm{O}$ into $\mathrm{N}_{2}$. A value close to 1 indicates a

poor ability of the soil to reduce $\mathrm{N}_{2} \mathrm{O}$ to $\mathrm{N}_{2}$ during the final step of denitrification.

NOE uses several soil parameters which can be measured following laboratory protocols: $D_{\mathrm{P}}$, the potential denitrification rate $\left(\mathrm{kg} \mathrm{N} \mathrm{ha}^{-1} \mathrm{~d}^{-1}\right), z_{N}$ the potential nitrification rate $\left(\mathrm{kg} \mathrm{N} \mathrm{ha}^{-1} \mathrm{~d}^{-1}\right)$, and $a$ and $b$, characterizing the response of nitrification to soil moisture (see appendix). The parameters $r$ and $D_{p}$ were determined from 16 samples collected at the shoulder and footslope positions, following the protocols proposed in Hénault and Germon (2000) and Hénault et al. (2001). The nitrification parameters $z_{N}, a$ and $b$ were based on measurements on the same soil type in a nearby region (Arrou site, Hénault et al., 2005) because the use of these parameters has also been validated by modelling $\mathrm{N}_{2} \mathrm{O}$ fluxes from soils of same type in the very close vicinity of the studied field (Gu et al., 2014). The spatial variability of the nitrification parameters has not been determined due to the low contribution of nitrification to $\mathrm{N}_{2} \mathrm{O}$ fluxes in this soil and to the very large time required for such measurements.

\section{Deterministic prediction:}

A deterministic model for each campaign based on soil properties at each site was tested by applying the model to individual sampling points, i.e. by using the measured soil WFPS and mineral nitrogen at an individual point for predicting the $\mathrm{N}_{2} \mathrm{O}$ flux at this point during the campaign. The agreement between predictions and measurements was tested by considering the Pearson's correlation between simulated and measured fluxes, and the root mean square error (RMSE).

\section{Stochastic simulation:}

Distribution simulations were performed when denitrification was identified as the main process source of $\mathrm{N}_{2} \mathrm{O}$, i.e. WFPS $>W_{1}$, as the spatial variability of the nitrification parameters has not been determined. The nitrification parameters were taken as constant and the denitrification part of NOE was used for estimating flux distributions by Monte Carlo (MC) algorithm rather than for predicting individual spatial fluxes. All calculations were made with MATLAB. A lognormal probability density function (pdf) was fitted by the maximum 
244 likelihood method to the measured frequency distribution of the model parameter $D_{p}$

245 (denitrification potential rate). Values of $D_{p}$ were then randomly selected from this pdf.

246

247

248

249

250

251

252

253

254

255

256

257

258

259

260

261

262

263

264

265

266

267

268

269

Input variables exhibiting a lognormal distribution were first log-transformed. All variables were centred and reduced. Then the Cholesky decomposition method was applied to take into account measured correlations between input variables (Webster and Oliver, 2007). For this purpose, the covariance matrix of the transformed variables was calculated for each campaign and the Cholesky matrix was calculated. Sets of variables were randomly generated by multiplying the Cholesky matrix by a random vector following the normal law $\mathrm{N}(0,1)$. Then, a back transformation of transformed variables was applied to generate values at the original scale.

These randomly generated variables were used as the driving variables of NOE for predicting a flux. The mean daily temperature was used in each case, because the flux measurements repeated at the beginning and end of each campaign showed that the range of temporal variation during the campaign was much smaller than the range of spatial variability, as previously reported by van den Heuvel et al. (2009). For each case simulation, 50000 runs were done to check the stability of the results. The simulated distributions were truncated at the 2.5 and $97.5 \%$ quantiles, to exclude unrealistic values due, for example, to extremely high or zero potential rates of denitrification. The simulated frequency distribution of the $\mathrm{N}_{2} \mathrm{O}$ fluxes was compared with the measured one by applying a $\chi^{2}$ homogeneity test ( $p$ $<0.05)$. For this purpose, the fluxes were systematically attributed to classes such that the theoretical number of data in each class was always 5 . The upper class, for which the theoretical number of data was less than 5 , was grouped with the previous one.

\section{Results}

\subsection{Measurements of $\mathrm{N}_{2} \mathrm{O}$ fluxes and soil variables}

The $\mathrm{N}_{2} \mathrm{O}$ fluxes were significantly larger during the 2011 campaigns $(\mathrm{T} 1, \mathrm{~S} 1)$ than during the 2012 campaigns ( $p<0.05$ for transects and $p<0.001$ for $S$ surfaces). The largest difference 
was measured between S1 and S3 (Fig. 3) and was almost one order of magnitude. The fluxes exhibited a large spatial variability and the minimum and maximum fluxes always differed by more than one order of magnitude even at the local scale (S). The frequency distributions for all the measurements were skewed and could be considered as lognormal (Table 1). The variation of frequency distributions over time was smaller at the S scale (CV from 68 to $96 \%$ ) than at the T scale (CV from 82 to $311 \%$ ). The largest CV was measured in T1 when a gradient of $\mathrm{N}_{2} \mathrm{O}$ fluxes was observed along the main slope. The $\mathrm{N}_{2} \mathrm{O}$ fluxes, $V W C$ and $\mathrm{NO}_{3}{ }^{-}$contents correlated with elevation in T1 but not in T2 and T3 $(p=0.57$ and 0.72 for T2 and T3, respectively).

The spatial variability of soil texture (Table 2 ) was similar to the variability previously reported at the field scale (e.g. Cambardella et al., 1994). No significant difference was found in the surface layer bulk density between locations. For T1, a significant correlation was observed between fluxes and WFPS $(p<0.001, r=0.78)$ and between fluxes and the $\mathrm{NO}_{3}{ }^{-}$content $(p<0.001, r=0.74)$. No significant correlation was found between $\mathrm{N}_{2} \mathrm{O}$ fluxes and soil variables for the other campaigns. Finally, WFPS usually exhibited normal distributions, whereas the mineral nitrogen distributions were nearly always asymmetrical (Table 1 and Fig. 4).

\subsection{Deterministic modelling of $\mathrm{N}_{2} \mathrm{O}$ fluxes}

The distribution of the $D_{\mathrm{p}}$ parameter could be considered as lognormal and calculation of the mean by the maximum likelihood method gave a value of $6.1 \mathrm{~kg} \mathrm{~N} \mathrm{ha}^{-1} \mathrm{~d}^{-1}$. The value measured for the $r$ parameter was 0.83 , indicating the relatively poor capacity of this soil to reduce $\mathrm{N}_{2} \mathrm{O}$ to $\mathrm{N}_{2}$. In this study, the WFPS was above the presumed threshold of denitrification $W_{1}$ in all campaigns except S3. Therefore, only a weak proportion of the flux was predicted to originate from nitrification i.e., $5 \%$ for $\mathrm{S} 1 ; 13 \%$ for $\mathrm{S} 2 ; 5 \%$ for $\mathrm{T} 1 ; 5 \%$ for T2 and $10 \%$ for T3. For $\mathrm{S} 3$, the predicted proportion of $\mathrm{N}_{2} \mathrm{O}$ produced by nitrification was $94 \%$ of the total flux. 
When all the data were plotted together, predicted and measured $\mathrm{N}_{2} \mathrm{O}$ fluxes were closely correlated $(r=0.73, p<0.001$, Table 3 and Figure 5 a.). The agreement was good when the mean predicted flux versus the mean measured flux was considered for each campaign (Fig. 5. b. and Table 3). This means that the model could successfully predict variations over time.

When each campaign was considered separately, the agreement between the predictions and the measurements per treatment was generally poor: the RMSE were as large as or larger than the mean measured flux and there was no significant correlation between the predicted and measured fluxes ( $p>0.1$ for S1, S2, S3, T2 and T3, Table 3). Nevertheless, a very good association between the predicted and measured data $(p<0.0001, r=0.88$, Fig. 5 a. and Table 3) together with reasonable accuracy (RMSE of $0.118 \mathrm{mg} \mathrm{N} \mathrm{m}^{-2} \mathrm{~h}^{-1}$ ), was obtained for T1.

\subsection{Modelling the relative frequency distributions of $\mathrm{N}_{2} \mathrm{O}$ fluxes.}

The measured distribution of the $D_{p}$ parameter was first fitted by a lognormal function to generate the pdf used for the MC simulations (Fig. 6). All asymmetrical distributions (Table 1) of soil input variables were log-transformed before applying the Cholesky method, regardless of whether the distribution was significantly different from a lognormal distribution, so as to render the distributions symmetrical.

The MC simulation was not applied to the $\mathrm{S} 3$ campaign because the main source of $\mathrm{N}_{2} \mathrm{O}$ was probably nitrification due to low WFPS. When applied to the other campaigns, the simulated and measured flux distributions were not significantly different for the S1 and S2 campaigns at the local scale or for the T1 and T3 campaigns at the transect scale $\left(\chi^{2}\right.$ test, $p>0.05$, Table 4 and Fig. 7). For the T2 campaign, the mean flux produced by MC simulation was significantly smaller than the measured mean flux ( $\chi^{2}$ test, $p<0.001$, Table 4$)$.

\section{Discussion}


321 The main aim of this study was to test the ability of a process-based model, NOE, to predict

322 spatial variations in $\mathrm{N}_{2} \mathrm{O}$ fluxes, by 1 ) predicting the individual $\mathrm{N}_{2} \mathrm{O}$ fluxes at a fine scale (field or few $\mathrm{m}^{2}$ ) and 2) stochastically simulating the frequency distributions of fluxes measured during spatial campaigns.

\subsection{Measured spatial variability of $\mathrm{N}_{2} \mathrm{O}$ fluxes:}

A quick flux measurement method involving a fast box was chosen for this study. It was extremely simple to use because it does not require special field preparation. Agreement between the measurements obtained by fast box and in static chambers was good (see supplementary material), which indicates that the fast-box method enabled to identify hotspots. Other authors have also recommended the fast box to minimize ecosystem disturbance due to long closure time (Flechard et al., 2007) and noted that, due to the rapid response of the QCL spectrometer, the number of measurements can be increased, and thus the opportunities for measuring the spatial variability of $\mathrm{N}_{2} \mathrm{O}$ fluxes. In the present study, the measured variability was consistent with the spatial variability of fine-scale studies described in the literature. Indeed, the flux distributions in these studies were often considered as lognormal (Ambus and Christensen 1994, Ball et al 1997, Röver et al 1999, Turner et al 2008, Konda et al., 2008, Nishina et al., 2009) and the CV generally ranged from $\sim 50 \%$ to $300 \%$ (e.g. Velthof et al., 1996, Ambus and Christensen, 1994, Turner et al., 2008).

\subsection{Overall quality of $\mathrm{N}_{2} \mathrm{O}$ flux predictions:}

340 Although models are generally used to predict temporal variations in $\mathrm{N}_{2} \mathrm{O}$ fluxes, they often 341 provide better predictions of cumulated fluxes over a season or year, than of daily variations 342 (Lehuger et al., 2009; Beheydt et al., 2007). For example, Jarecki et al. (2008) reported a correlation coefficient of 0.37 between measured and predicted fluxes with the DAYCENT

344 model, and Beheydt et al. (2007) reported RMSE values of between 0.7 and $1.4 \mathrm{mg} \mathrm{N} \mathrm{m}^{-2} \mathrm{~h}^{-1}$

345 for maximum $\mathrm{N}_{2} \mathrm{O}$ flux values of about $3.3 \mathrm{mg} \mathrm{N} \mathrm{m}^{-2} \mathrm{~h}^{-1}$ with the DNDC model in long-term 346 field experiments. Hergoualc'h et al. (2009) used two rate-limiting models (NOE and NGAS) 347 to predict the temporal dynamics of $\mathrm{N}_{2} \mathrm{O}$ fluxes on Costa-Rican coffee plantations and 
reported that the correlation coefficient between measured and predicted fluxes was 0.57 with a daily time step and 0.94 with a seasonal time step. The RMSE in this study was below $0.04 \mathrm{mg} \mathrm{N} \mathrm{m}^{-2} \mathrm{~h}^{-1}$ for maximum $\mathrm{N}_{2} \mathrm{O}$ flux values of about $1 \mathrm{mg} \mathrm{N} \mathrm{m}^{-2} \mathrm{~h}^{-1}$. In our study, the only campaign in which we observed a good match between measured and predicted fluxes was $\mathrm{T} 1$, with a correlation coefficient of 0.88 and an RMSE of $0.188 \mathrm{mg} \mathrm{N} \mathrm{m}^{-2} \mathrm{~h}^{-1}$ for a measured range of about 0 to $1.35 \mathrm{mg} \mathrm{N} \mathrm{m}^{-2} \mathrm{~h}^{-1}$ (Tables 1 and 3). Thus the RMSE was smaller than the RMSE reported by Beheydt et al. (2007) but larger than that reported by Hergoualc'h et al. (2009). However the temporal variability between campaigns can be determined from the predicted mean flux at each date (6 points, cf Fig. 5.b.) and the resulting RMSE is then 0.058 $\mathrm{mg} \mathrm{N} \mathrm{m}^{-2} \mathrm{~h}^{-1}$ (Table 3), which is within the range of the RMSE values reported by Hergoualc'h et al. (2009).

Very few studies aimed at the spatial prediction of individual $\mathrm{N}_{2} \mathrm{O}$ fluxes, especially at a fine spatial scale. Milne et al. (2005) and Stacey et al. (2006) used the same flux database from cores sampled along a 1-km transect on the same day. Both studies were intended for the assessment and optimization of models, and multiplicative models based on rate-limiting functions, i.e. based on similar principles to NOE, were tested. A correlation coefficient $r=0.67$ to 0.7 (Milne et al., 2005) and an RMSE between 36 and $52 \mu \mathrm{g} \mathrm{N} \mathrm{kg}^{-1} \mathrm{~d}^{-1}$ were reported for $\mathrm{N}_{2} \mathrm{O}$ fluxes ranging from 0 to about $300 \mu \mathrm{g} \mathrm{N} \mathrm{kg}^{-1} \mathrm{~d}^{-1}$ (Stacey et al., 2006). If it is assumed that, in our study, $\mathrm{N}_{2} \mathrm{O}$ was only produced in the top $25 \mathrm{~cm}$ of soil, then the RMSE for the $\mathrm{T} 1$ campaign was $2.10 \mu \mathrm{g} \mathrm{Ng}^{-1} \mathrm{~d}^{-1}$ for $\mathrm{N}_{2} \mathrm{O}$ fluxes ranging from 0 to $24 \mu \mathrm{g} \mathrm{N} \mathrm{kg}{ }^{-1} \mathrm{~d}^{-1}$. The performance of the NOE model was therefore quite similar to that reported in the above studies, but only for the T1 campaign. This emphasizes the need to evaluate models spatially at several dates.

When used deterministically, the NOE model reproduced the T1 campaign well, but poorly predicted the individual $\mathrm{N}_{2} \mathrm{O}$ fluxes in the other $\mathrm{T}$ (T2-T3) and the three $\mathrm{S}$ campaigns. A clear correlation between $\mathrm{N}_{2} \mathrm{O}$ fluxes, WFPS, $\mathrm{NO}_{3}{ }^{-}$contents and field elevation was only observed for the T1 campaign. In this case, the distribution of nutrients and water along the transect 
was probably controlled by topography-induced transfer, which in turn controlled the $\mathrm{N}_{2} \mathrm{O}$ fluxes. Similar effects have been reported for denitrification by Pennock et al. (1992) and for $\mathrm{N}_{2} \mathrm{O}$ fluxes by Nishina et al., (2009) and Vilain et al. (2010). This effect may only be occasional because conditions during the early spring of 2012 were very dry and the field slope is gentle (1.6\%), which would explain why an effect was not measured in T2 and T3. The good prediction of individual $\mathrm{N}_{2} \mathrm{O}$ fluxes for the $\mathrm{T} 1$ campaign can be explained by the good correlation of both the $\mathrm{N}_{2} \mathrm{O}$ fluxes and model input variables at the same elevation.

The MC simulation of flux distribution could be tested under conditions favorable for denitrification, i.e. $\mathrm{T} 1, \mathrm{~T} 2, \mathrm{~T} 3, \mathrm{~S} 1$ and $\mathrm{S} 2$, but not $\mathrm{S} 3$ when nitrification was probably dominant. The simulated and observed flux distributions were not significantly different, except for the T2 campaign. We hypothesize that the T2 results were influenced by the associated meteorological conditions. The T1, T3 and S2 campaigns were carried out under sunny conditions after at least 3 dry days. Only $\mathbf{S 1}$ was conducted in wet soil, after a minor rain event ( $8.2 \mathrm{~mm}$ within 3 days), and there was probably very little evaporation as the relative humidity remained at $95 \%$ throughout the day. In contrast, the T2 campaign was carried out on the first sunny day after 5 days of rain (12 mm from 2-7 March 2013) following a dry period. It has often been reported that peak $\mathrm{N}_{2} \mathrm{O}$ production is triggered by soil rewetting (Kim et al., 2012). Thus, one possible explanation may be that the model cannot reproduce correctly $\mathrm{N}_{2} \mathrm{O}$ fluxes during the transitory period following rewetting, although no conclusion can be drawn from this single campaign. Although a satisfactory agreement between the predicted and measured fluxes was only obtained for $\mathrm{T} 1$, the measured distributions could be reproduced in 4 cases out of 5 : two out of three at the scale of $\sim 10 \mathrm{~m}^{2}$ (S1 and S2) and 2 at the transect scale (T1 and T3). This suggests that the interactions between control variables are adequately represented by the model. The deterministic prediction at very local scale fails because soil variable measurements are not representative of the volume where $\mathrm{N}_{2} \mathrm{O}$ is produced. But the correct representation of the denitrification 
401

402

403

404

405

406

407

408

409

410

411

412

413

414

415

416

417

418

419

420

421

422

423

424

425

426

427

process by the model enables to estimate the flux distributions from the soil variable distributions.

\subsection{Interest of simulating distributions:}

As the frequency distributions of flux change over time, it is important to test the ability of a model to reproduce the range of measured distributions (Yates et al., 2006). Even if the location of largest $\mathrm{N}_{2} \mathrm{O}$ fluxes, and thus the spatial pattern of $\mathrm{N}_{2} \mathrm{O}$ fluxes, cannot be correctly predicted, the frequency distribution can provide information about the range of variations in $\mathrm{N}_{2} \mathrm{O}$ flux.

Flux distributions were simulated from the measured distributions of their controlling factors. Assessments of the flux range can be used to determine an appropriate number of soil measurements. A resampling method, for example, was used to estimate the number of measurements $(n)$ which would have been required to simulate an estimated mean flux within $\pm 10 \%$ of the true mean at the $95 \%$ uncertainty level, under the conditions measured during campaigns where denitrification was found to be dominant. The distributions fitted to the measured WFPS and $\mathrm{NO}_{3}^{-}$content distributions were assumed to be the true distributions and the $\mathrm{N}_{2} \mathrm{O}$ flux distribution resulting from applications of the NOE model was assumed to be the true $\mathrm{N}_{2} \mathrm{O}$ flux distribution. The $\mathrm{n}$ samples were randomly selected within these distributions. These data were then used as input for the NOE model and the mean $\mathrm{N}_{2} \mathrm{O}$ flux was estimated by maximum likelihood method and compared to the mean of the real flux distribution. The number of measurements required to obtain a $10 \%$ level of uncertainty was $65,100,210,205$ and 390 for S1, S2, T1, T2 and T3, respectively. This is still of interest because in many cases, it is simpler to ensure extensive coverage of the soil variables rather than of the $\mathrm{N}_{2} \mathrm{O}$ fluxes. These large numbers of measurements also need to be compared with the number of $\mathrm{N}_{2} \mathrm{O}$ flux measurements required to obtain the same uncertainty for the mean flux reported in other spatial studies. For example, Folorunso and Rolston (1984) claimed that between 156 and 4117 measurements would be required to obtain a sample mean within $\pm 10 \%$ of the true mean of the In-transformed flux, and that this 
result could not be used to determine the non-transformed flux. However the quantification of fluxes at a given scale depends on information about the mean non-transformed flux.

Practically, even if it is not possible to provide such a large number of measurements, this study emphasizes the need to focus spatial sampling effort on peak periods of $\mathrm{N}_{2} \mathrm{O}$ fluxes due to the transitory character of these fluxes. Accumulation chambers remain the most widely used technique for such measurements due to their simplicity. So a correct simulation of the flux distribution during the periods of large fluxes would enable improving the estimation of total flux without bias due to low sampling coverage. A further step into the modelling of spatial variability of fluxes would then be to provide parameterization for the simulation of the distribution of soil variables with an agro-ecosystem model, before using these simulated distributions as input of the NOE model. This would in turn be useful to take into account the local spatial variability and measurement uncertainty in model up-scaling (Whelan and Gandolfi, 2002).

The general agreement of our measurements with previous studies suggests that our case can provide a good example of the spatial variability in $\mathrm{N}_{2} \mathrm{O}$ fluxes from croplands. Although the method needs to be further investigated with different soil types and different crops, the findings imply that it could be useful for simulating flux distributions at other sites with similar ranges of WFPS and soil mineral nitrogen content.

\section{Conclusion}

$\mathrm{N}_{2} \mathrm{O}$ fluxes, like many soil properties, display a very large spatial variability and it is important to quantify the range of this variation in the form of a confidence interval or even better by describing the frequency distributions of such variations, even in modelling studies. The aim of this study was to test the feasibility of predicting spatial variations in $\mathrm{N}_{2} \mathrm{O}$ fluxes from cropped soils by applying the simple process-based model NOE. It is generally recognized that, at such fine scale, linking hotspots to soil properties or predicting individual fluxes is difficult, which certainly explains why the simulation did not match the measured fluxes in all but one campaign. For this transect campaign, a spatial flux pattern was observed, probably 
455 linked to a strong gradient of soil water content along the slight slope of the field due to the

456 climatic conditions. It is thus important to evaluate spatial simulations at different dates.

457 The stochastic simulation of distributions with the denitrification part of the NOE model was 458 then tested as spatial information on nitrification parameters were not available. Input

459

460

461

462

463

464

465

466

467

468

469

470

471

472

473

474

475

$476 \quad \mathrm{~F}_{\mathrm{N}}$ and $\mathrm{F}_{\mathrm{W}}$ are the effects of soil $\mathrm{NO}_{3}{ }^{-}$content $\left(\left[\mathrm{NO}_{3}{ }^{-}\right], \mathrm{mg} \mathrm{N} \mathrm{kg}^{-1}\right)$ and water-filled pore space

477 (WFPS) respectively.

478 variables were randomly generated taking into account the measured distributions of the input variables and possible correlations between them. For one campaign, the dominant microbial process producing $\mathrm{N}_{2} \mathrm{O}$ was probably nitrification due to low WFPS. The stochastic simulation was tested for the other 5 campaigns and satisfactorily simulated $\mathrm{N}_{2} \mathrm{O}$ fluxes in 4 of these 5 cases, two at the local scale $\left(\sim 10 \mathrm{~m}^{2}\right)$ and two at the transect scale. The reason of failing for the $5^{\text {th }}$ case has to be further investigated. Nevertheless this suggests that the NOE model provides an adequate simulation of $\mathrm{N}_{2} \mathrm{O}$ flux distribution within this range of WFPS. Simple process-based models of fluxes, such as NOE, could thus serve as useful tools for simulating flux distributions and describing the range of variations in $\mathrm{N}_{2} \mathrm{O}$ fluxes at the withinfield scale.

\section{Acknowledgments}

We gratefully acknowledge A. Ayzac, G. Giot, C. Pasquier, C. Lelay and P. Courtemanche for their technical assistance during field measurements. This work was supported by the Région CENTRE, the Fonds Européen de Développement Régional (FEDER) and INRA through the SPATIOFLUX Project, and also by the Labex Voltaire (ANR-10-LABX-100-01).

\section{Appendix: Equations in NOE}

Denitrification functions: 
$479 \quad F_{N}=\frac{\left\lfloor\mathrm{NO}_{3}^{-}\right\rfloor}{k m_{1}+\left[\mathrm{NO}_{3}^{-}\right]}$

480

481

482

483

484

485

486

487

488

489

$490 \quad F_{T}(T)=N_{T}(T)=\left\{\begin{array}{l}\exp \left(\frac{(T-11) \cdot \ln (89)-9 \cdot \ln (2)}{10}\right) \text { if } \mathrm{T}<11^{\circ} \\ \exp \left(\frac{(T-20) \cdot \ln (2 \cdot 1)}{10}\right) \text { if } \mathrm{T} \geq 11^{\circ}\end{array}\right.$

$$
N_{W}(W F P S)=a \cdot G W C+b=a \cdot W F P S \cdot\left(\frac{1}{B D}-\frac{1}{2.65}\right)+b
$$

The response function of temperature $\left(T\right.$ in $\left.{ }^{\circ} \mathrm{C}\right)$ is common to both processes:

491

\section{Bibliography:}

492

493

494

495

496
Ambus, P., Christensen, S., 1994. Measurement of $\mathrm{N}_{2} \mathrm{O}$ emission from a fertilized grassland: an analysis of spatial variability. Journal of Geophysical Research 99, 16549-16555.

Ball, B.B., Horgan, G.W., Clayton, H., Parker, J.P., 1997. Spatial variability of nitrous oxide fluxes and controlling soil and topographic factors. Journal of Environmental Quality, 26, 399-409. 
Beheydt, D., Boeckx, P., Sleutel, S., Li, C., Van Cleemput, O., 2007. Validation of DNDC for 22 long-term $\mathrm{N}_{2} \mathrm{O}$ field emission measurements. Atmospheric Environment 41, 61966211.

Cambardella, C. A., Moorman, T. B., Parkin, T. B., Karlen, D. L., Novak, J. M., Turco, R. F., \& Konopka, A. E., 1994. Field-scale variability of soil properties in central lowa soils. Soil Science Society of America Journal, 58(5), 1501-1511.

Flechard, C., P. Ambus, U. Skiba, R.M. Rees, A. Hensen et al., 2007. Effects of climate and management intensity on nitrous oxide emissions in grassland systems across Europe, Agriculture, Ecosystems and Environment 121, 135-152.

Folorunso, O., Rolston, D., 1984. Spatial variability of field-measured denitrification gas fluxes. Soil B., Science society of America Journal 48, 1214-1219.

Gabrielle, P. Laville, O. Duval, B. Nicoullaud, J. C. Germon, C. Hénault, 2006, Processbased modeling of nitrous oxide emissions from wheat-cropped soils at the subregional scale, 20.

Gogo, S., Guimbaud C., Laggoun-Défarge F., Catoire V., Robert C. 2011, In situ quantification of $\mathrm{CH}_{4}$ bubbling events from a peat soil using a new infrared laser spectrometer, Journal of Soils and Sediments 11, 545-551

Groffman, P.M., Butterbach-Bahl, K., Fulweiler, RW., Gold, A.J., Morse, J.L., Stander, E.K., Tague, C., Tonitto, C., Vidon, P., 2009. Challenges to incorporating spatially and temporally explicit phenomena (hotspots and hot moments) in denitrification models, Biogeochemistry 93, 49-77.

Gu, J., Nicoullaud, B., Rochette, P., Pennock, D.J., Hénault, C., Richard, G., 2011. Effect of topography on nitrous oxide emissions from winter wheat fields in central France. Environmental Pollution 159, 3149-3155.

Gu, J., Loustau, D., Hénault, C., Rochette, P., Cellier, P., Nicoullaud, B., Grossel, A., Richard, G., 2014. Modeling nitrous oxide emissions from tile-drained winter wheat fields in Central France, Nutrient Cycling in Agroecosystems, 98, 27-40. 
524 Guimbaud, C., Catoire, V., Gogo, S., Robert, C., Chartier, M., Laggoun-Défarge, F., Grossel, A., Albric, P., Pomathiod, L., Nicoullaud, B., Richard, G., 2011. A portable infrared laser spectrometer for flux measurements of trace gases at the geosphere-atmosphere interface. Measurement Science and technology 22, 1-17.

Hashimoto, S., Morishita, T., Sakata, T., Ishizuka, S., Kaneko, S., and Takahashi, M. 2011. Simple models for soil $\mathrm{CO}_{2}, \mathrm{CH}_{4}$ and $\mathrm{N}_{2} \mathrm{O}$ fluxes calibrated using a Bayesian approach and multi-site data. Ecological Modelling, 222(7), 1283-1292.

Hénault C., Germon, J.C., 2000 NEMIS, a predictive model of denitrification on the field scale. European Journal of Soil Science 51, 257-270

Hénault ,C, Chèneby, D, Heurlier, K, Garrido, F., Perez, S., Germon, J. C., 2001. Laboratory kinetics of soil denitrification are useful to discriminate soils with potentially high levels of $\mathrm{N}_{2} \mathrm{O}$ emission on the field scale. Agronomie, 21, 713-723.

Hénault, C., Bizouard, F., Laville, B., Nicoullaud, B., Germon, J.C., Cellier, P., 2005. Predicting in situ $\mathrm{N}_{2} \mathrm{O}$ emission using NOE algorithm and soil database. Global Change Biology 11, 115-127.

Hensen, A., Groot, T., van den Bulk, W., J.E. Olesen, A.V., Schelde, K., 2006. Dairy farm $\mathrm{CH}_{4}$ and $\mathrm{N}_{2} \mathrm{O}$ emissions, from one square meter to the full farm scale. Agriculture, Ecosystems and Environment 112, 146-152.

Hergoualc'h, K., Harmand, J.M., Cannavo, P., Skiba, U., Oliver, R., Hénault, C., 2009. The utility of process-based models for simulating $\mathrm{N}_{2} \mathrm{O}$ emissions from soils: A case study based on Costa Rican coffee plantations. Soil Biology and Biochemistry 41, 23432355 .

Hutchinson, G., Mosier, A., 1981. Improved soil cover method for field measurement of nitrous oxide fluxes. Soil Science Society of America Journal 45, 311-316.

IUSS Working Group WRB, 2006. World reference base for soil resources 2006. 2nd edition. World Soil Resources Reports No. 103. FAO, Rome. 
Jarecki, M.K., Parkin, T.B., Chan, A.S., Hatfield, J.L., Jones, R., 2008. Comparison of Daycent-simulated and measured nitrous oxide emissions from a corn field. Journal of Environmental Quality 37, 1685-1690.

Kim, D.G., Vargas, R., Bond-Lamberty, B., Turetsky, M.R., 2012. Effects of soil rewetting and thawing on soil gas fluxes: a review of current literature and suggestions for future research. Biogeosciences 9, 2459-2483.

Konda, R, S.O., Ishizuka, S., Arai, S., Ansori, S., Tanaka, N., Hardjono, A., 2008. Spatial structures of $\mathrm{N}_{2} \mathrm{O}, \mathrm{CO}_{2}$, and $\mathrm{CH}_{4}$ fluxes from acacia mangium plantation soils during a relatively dry season in Indonesia. Soil Biology and Biochemistry 40, 3021-3030.

Lamers, M., J. Ingwersen, and T. Streck, 2007. Modelling $\mathrm{N}_{2} \mathrm{O}$ emission from a forest upland soil: A procedure for an automatic calibration of the biogeochemical model ForestDNDC. Ecological Modelling. 205. 52-58

Lehuger, S., B. Gabrielle, M. van Oijen, D. Makowski, J.-C. Germon, T. Morvan, C. Hénault, 2009, Bayesian calibration of the nitrous oxide emission module of an agroecosystem model. Agriculture, Ecosystems and Environment, 133, 208-222

Lugato, E., Zuliani, M., Alberti, G., Vedove, G. D., Gioli, B., Miglietta, F., Peressotti, A. (2010). Application of DNDC biogeochemistry model to estimate greenhouse gas emissions from Italian agricultural areas at high spatial resolution. Agriculture, ecosystems \& environment, 139(4), 546-556.

Mathieu, O., Lévêque, J., Hénault, C., Milloux, M., Bizouard, F., Andreux, F., 2006. Emissions and spatial variability of $\mathrm{N}_{2} \mathrm{O}, \mathrm{N}_{2}$ and nitrous oxide mole fraction at the field scale revealed with ${ }^{15} \mathrm{~N}$ isotopic techniques. Soil Biology and Biogemistry 38, 941951.

Milne, A.E., Lark, M.E., Addiscott, T.M., Goulding, W.T., Webster, C.P.and O'Flaherty, S., 2005. Wavelet analysis of the scale- and location-dependent correlation of modelled and measured nitrous oxide emissions from soil. European Journal of Soil Science $56,3-17$ 
577 Nishina, K., Takenaka, C., Ishizuka, S., 2009. Spatial variations in nitrous oxide and nitric oxide emission potential on a slope of Japanese cedar (cryptomeria japonica) forest. Soil Science and Plant Nutrition 55, 179-189.

Parkin, T.P., 1987. Soil microsites as a source of denitrification variability. Soil Science Society of America Journal 51, 1194-1199.

Parkin, T., Cheisinger, J., Chester, S., Satarr, J., Robinson, J., 1988. Evaluation of statistical estimation methods for log-normally distributed variables. Soil Science Society of America Journal 52, 323-329.

Parkin, T.B., and Robinson, J.A., 1989. Stochastic models of soil denitrification. Applied and Environmental Microbiology, 55, 72-77.

Pedersen, A., Petersen, S., Schelde, K., 2010. A comprehensive approach to soilatmosphere trace-gas flux estimation with static chambers. European Journal of Soil Science 61, 888-902.

Pennock, D., van Kessel, C., Farrell, R., Sutherland, R., 1992. Landscape- scale variations in denitrification. Soil Science Society of America Journal. 56, 770-776.

Pringle, M. J., Baxter, S. J., Marchant, B. P., Lark, R. M. 2008. Spatial analysis of the error in a model of soil nitrogen. Ecological Modelling, 211, 453-467.

Robert, C., 2007. Simple, stable, and compact multiple-reflection optical cell for very long optical paths. Applied Optics 46, 5408-5418.

Röver, M., Heinemeyer, O., Munch, J.C., Kaiser, E.A., 1999. Spatial heterogeneity within the plough layer: high variability of $\mathrm{N}_{2} \mathrm{O}$ emission rates. Soil Biology and Biochemistry 31 , 167-173.

Skiba, U., Smith, K.A., 2000. The control of nitrous oxide emission from agricultural and natural soils. Chemosphere - Global Change Science 2, 379-386

Stacey, K.F., R.M. Lark, A.P. Whitmore, A.E. Milne, 2006, Using a process model and regression kriging to improve predictions of nitrous oxide emissions from soil, Geoderma. 135, 107-117 
604

605

606

607

608

609

610

611

612

613

614

615

616

617

618

619

620

621

622

623

624

625

Stehfest, E., Bouwmann, L., 2006. $\mathrm{N}_{2} \mathrm{O}$ and $\mathrm{NO}$ emission from agricultural fields and soils under natural vegetation: summarizing available measurement data and modelling of global annual emissions. Nutrient Cycling in Agroecosystems, 74, 207-228.

Turner, D.A., Chen, D., Galbally, I.E., Leuning, R., Edis, R.B., Li, Y., Kelly, K., Phillips, F., 2008. Spatial variability of nitrous oxide emissions from an Australian irrigated dairy pasture. Plant Soil 309, 77-88.

Van den Heuvel, R., Hefting, M., Tan, N., Jetten, M., Verhoeven, J., 2009. $\mathrm{N}_{2} \mathrm{O}$ emission hotspots at different spatial scales and governing factors for small scale hotspots. Science of the total Environment 407, 2325-2332.

Velthof, G., Jarvis, S., Stein, A., Allen, A., Oenema, O., 1996. Spatial variability of nitrous oxide fluxes in mown and grazed grasslands on a poorly drained clay soil. Soil Biology and Biochemistry 28, 1215-1225.

Vilain, G., Garnier,J., Tallec, G., Cellier, P. 2010, Effect of slope position and land use on nitrous oxide emissions. Agricultural and forest Meteorology, 150, 1192-1202

Webster, R., and Oliver, M. A. (2007). Geostatistics for environmental scientists. John Wiley \& Sons.

Whelan, M., Gandolfi, C., 2002. Modelling of spatial controls on denitrification at the landscape scale. Hydrological processes 16, 1437-1450.

Yates, T.T., Si, B.C., Farrell, R.E., Pennock, D.J., 2006. Probability distribution and spatial dependence of nitrous oxide emission: Temporal change in hummocky terrain. Soil Science Society of America Journal 70, 753-762. 
626

627

628

629

630

631

632

633

634

635

636

637

638

639

640

641

642

643

Figures:

Figure 1: Study plot. The black dots show sampling points on the T1 and T2 transects $(150 \mathrm{~m} \times 12 \mathrm{~m})$. The grey squares indicate the places where the $3 \times 3 \mathrm{~m}^{2}$ surfaces were sampled in the dense surface sampling experiments.

Figure 2: Basic principle of the NOE model. See text for details.

Figure 3: $\mathrm{N}_{2} \mathrm{O}$ fluxes measured at spatial (S) (left) and at transect (T) scales (right).

Horizontal axes indicate distance $(\mathrm{m})$.

Figure 4: Measured frequency distributions of WFPS (left), $\mathrm{NO}_{3}{ }^{-}$content (middle) and $\mathrm{NH}_{4}{ }^{+}$ content (right). Blue line shows the normal or lognormal fitted pdf.

Figure 5 a. Predicted fluxes versus measured fluxes for the deterministic simulation. b. Mean predicted fluxes versus mean measured fluxes for each campaign for the deterministic simulation. The dashed black line is the linear fit of the deterministic results. The thick black line indicates the 1 to 1 line.

Figure 6: Frequency distribution of the potential denitrification parameter $D p$. Blue line shows the lognormal fitted pdf.

Figure 7: Measured frequency distributions of $\mathrm{N}_{2} \mathrm{O}$ fluxes (left) and simulated distributions (right). Blue line shows the lognormal fitted pdf. 
644 Table

645 Table 1: Summary statistics of measured variables. For the distributions, $\mathrm{n}$ indicates 646 normality, In lognormality and $x$ indicates that both possibilities were rejected. $F\left(N_{2} O\right)$ is the $647 \mathrm{~N}_{2} \mathrm{O}$ flux in $\mathrm{mg} \mathrm{N} \mathrm{m}^{-2} \mathrm{~h}^{-1}$, WFPS the water filled pore space, $\mathrm{NO}_{3}^{-}$and $\mathrm{NH}_{4}^{+}$the $\mathrm{NO}_{3}^{-}$and $648 \mathrm{NH}_{4}{ }^{+}$content in $\mathrm{mg} \mathrm{N} \mathrm{kg}^{-1}$ soil.

649 Table 2: Soil properties along the transect. Units are $\mathrm{g} \mathrm{kg}^{-1}$ except for $\mathrm{C} / \mathrm{N}$ ratio and $\mathrm{pH}$.

650 Table 3: Summary of deterministic simulation results. Mean fluxes are given in $\mathrm{mg} \mathrm{N} \mathrm{m}^{-2} \mathrm{~h}^{-1}$.

651 Table 4: Summary of results from the distribution simulation. Mean fluxes are given in $652 \mathrm{mg} \mathrm{N} \mathrm{m}^{-2} \mathrm{~h}^{-1}$. Bold characters indicate that the $\chi^{2}$ test shows no significant differences 653 between the measured and simulated distributions. 


\section{Figure 1: \\ 2}

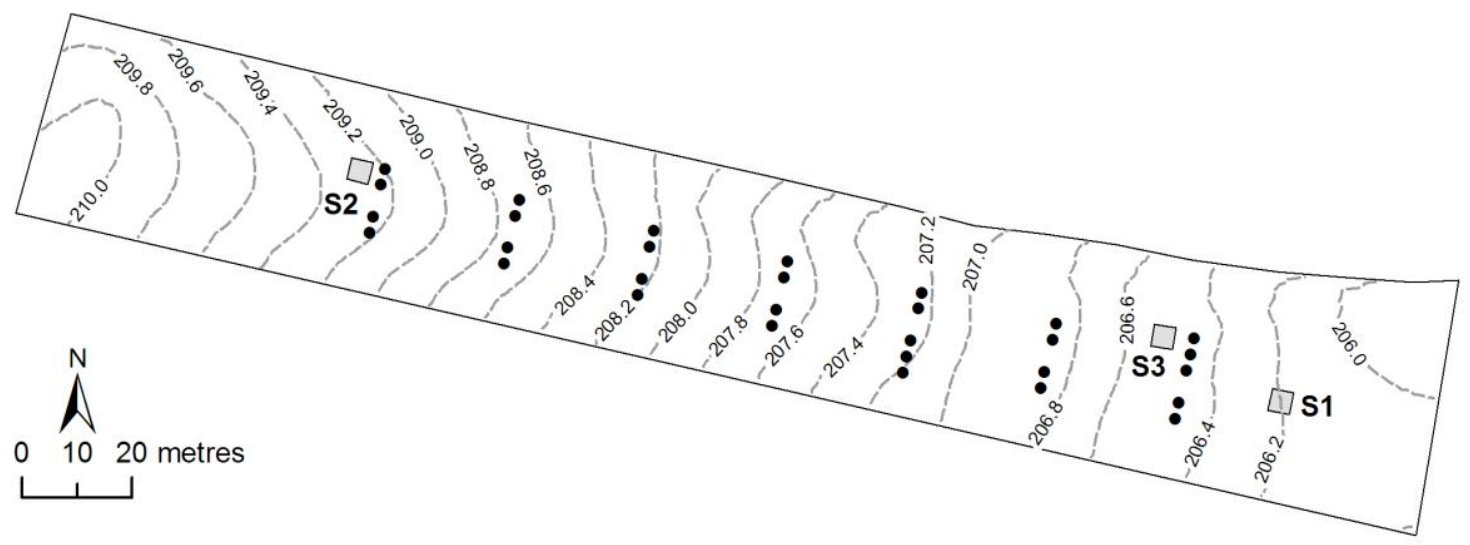


$1 \quad$ Figure 2

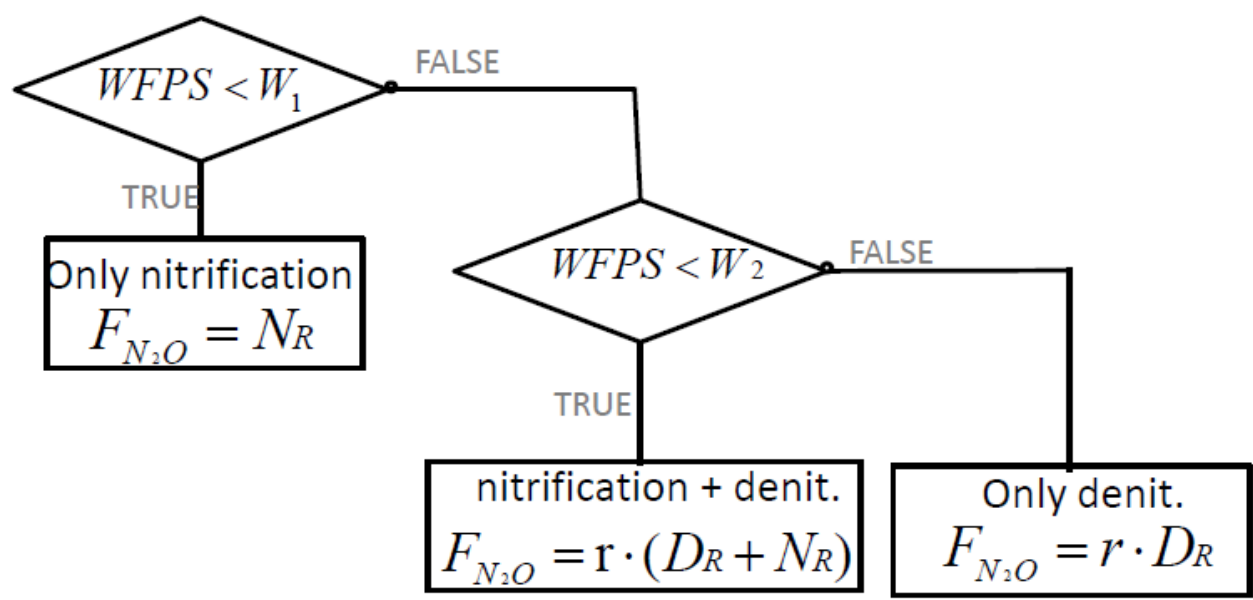

Where:

$$
\begin{array}{cc}
N_{R}=\mathrm{Z}_{\mathrm{N}} \cdot N_{T}(T) \cdot N_{N}\left(N_{4}\right) \cdot N_{W}(W F P S) & D_{R}=\mathrm{D}_{\mathrm{p}} \cdot F_{T}(T) \cdot F_{N}\left(N O_{3}\right) \cdot F_{W}(W F P S) \\
\text { Nitrification rate } & \text { Denitrification rate }
\end{array}
$$


1 Figure 3

2

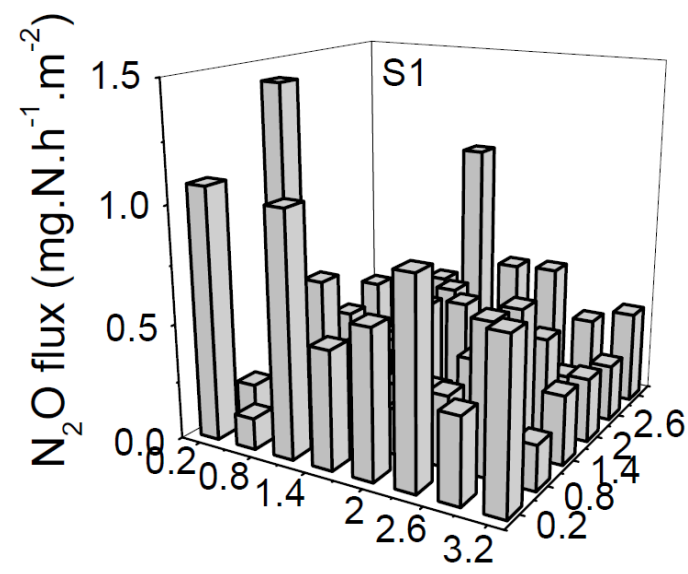

3
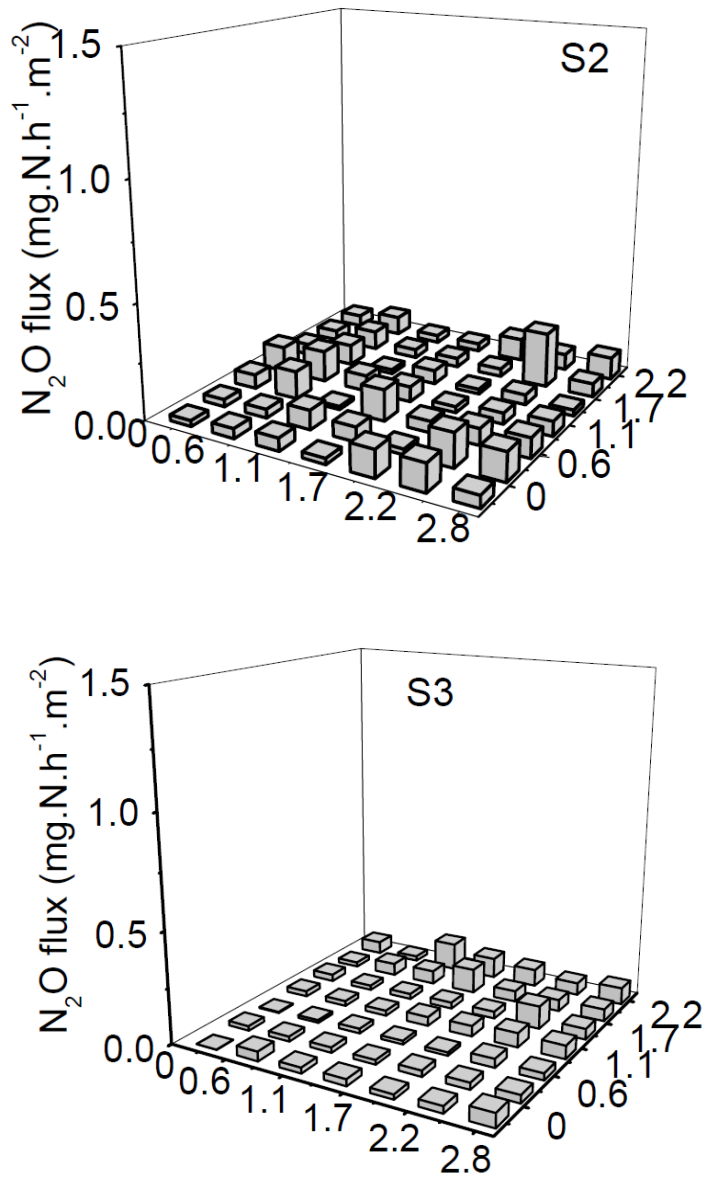
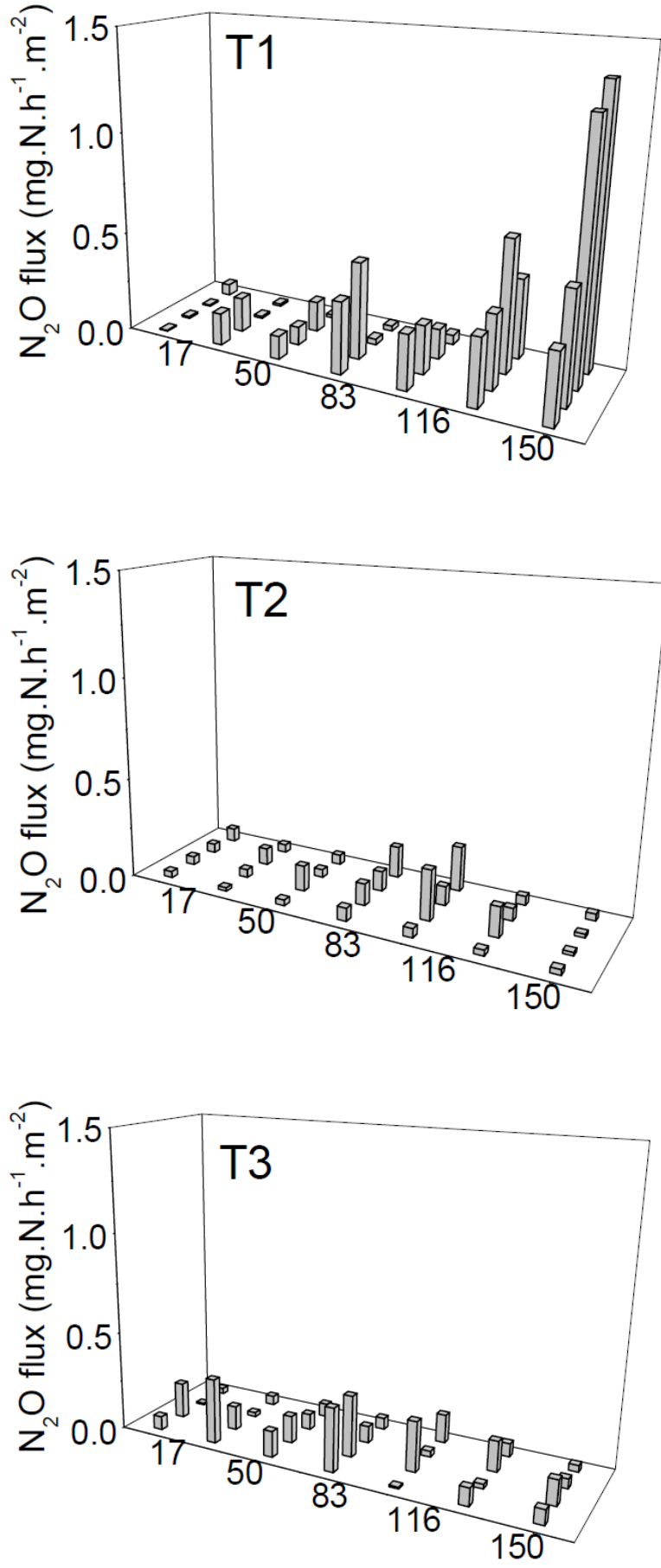
1 Figure 4
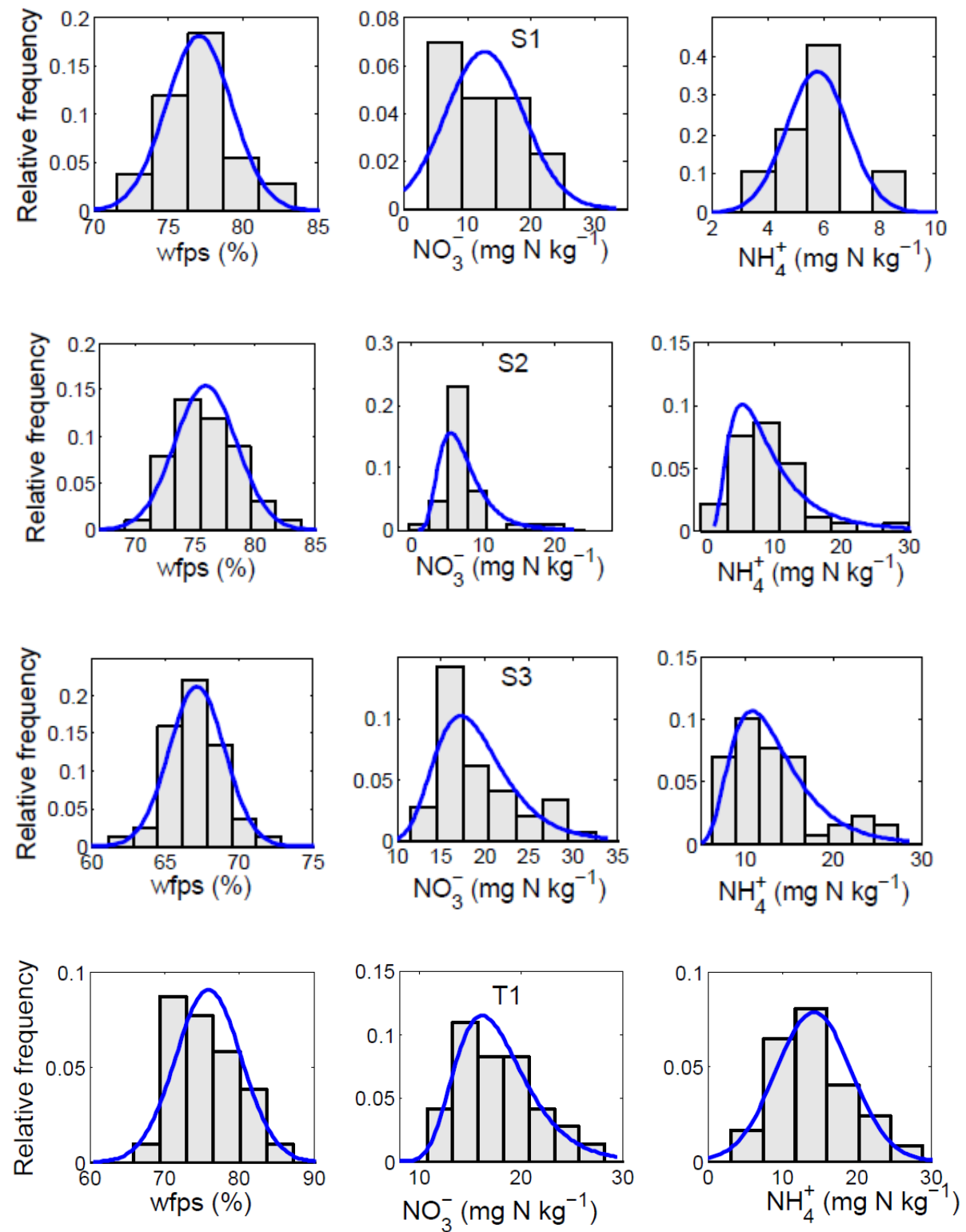

5
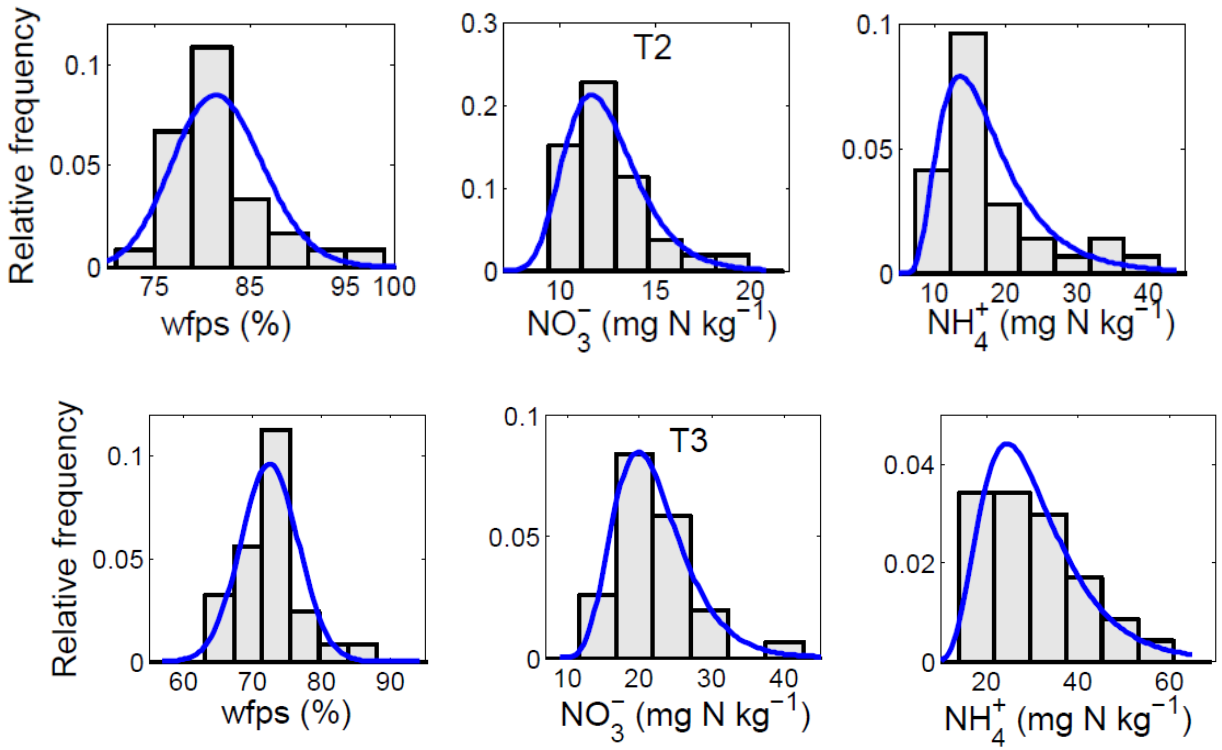


\section{Figure 5}

2 a.

3

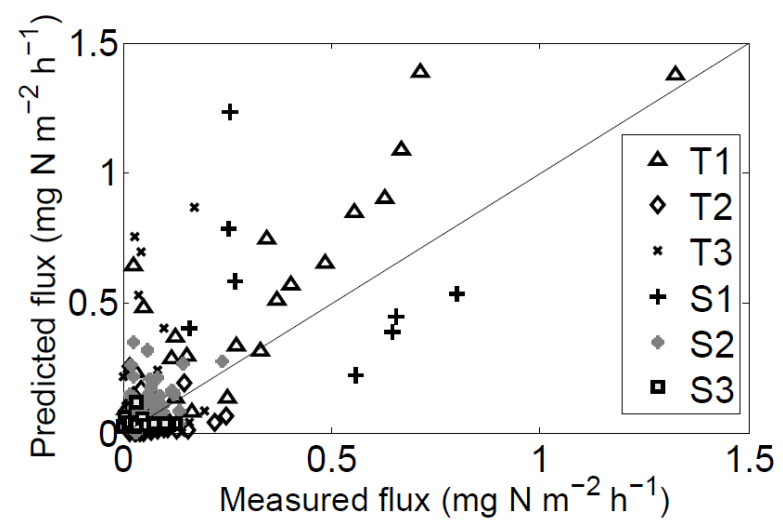

4

b.

5

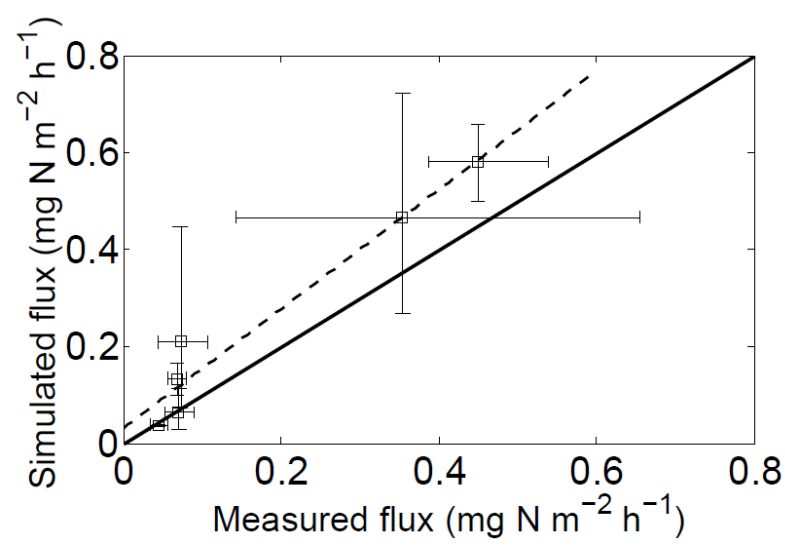

6 
$1 \quad$ Figure 6

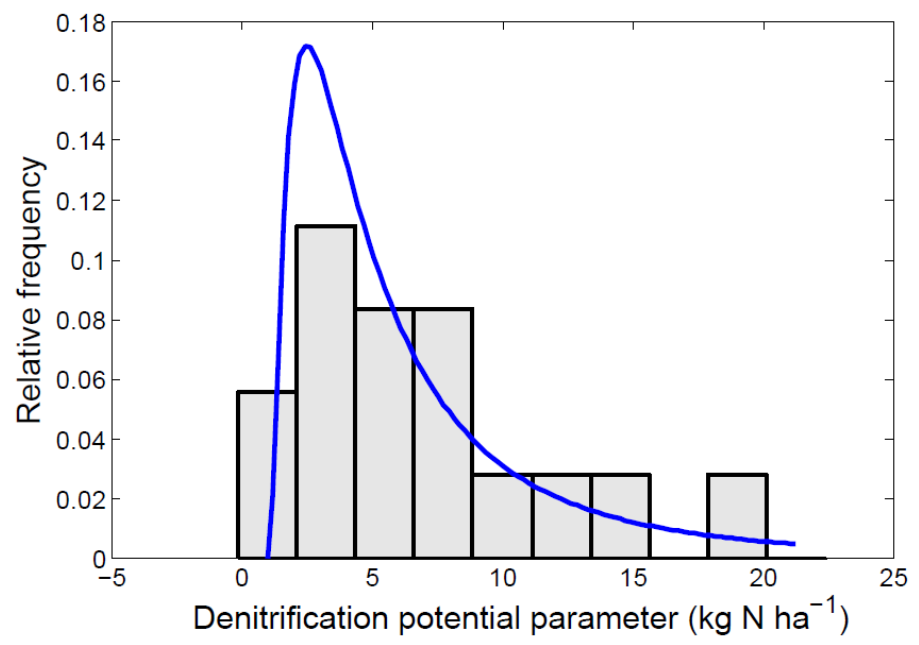


1 Figure 7

2
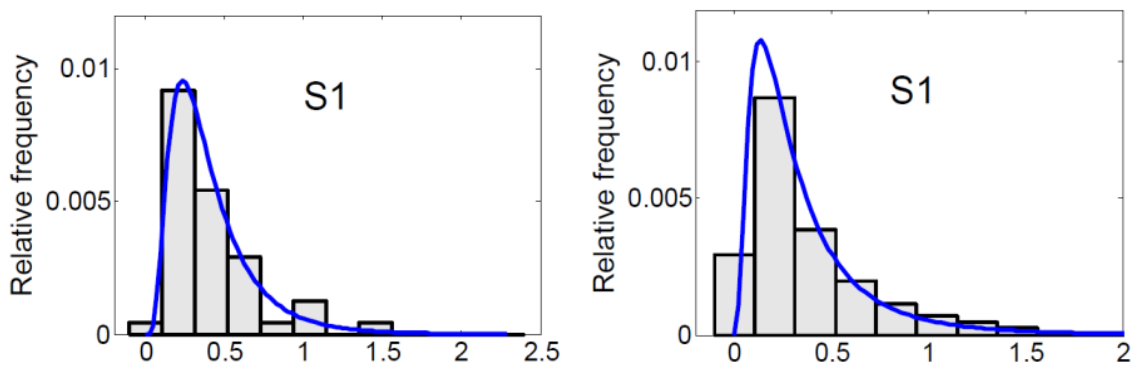

3
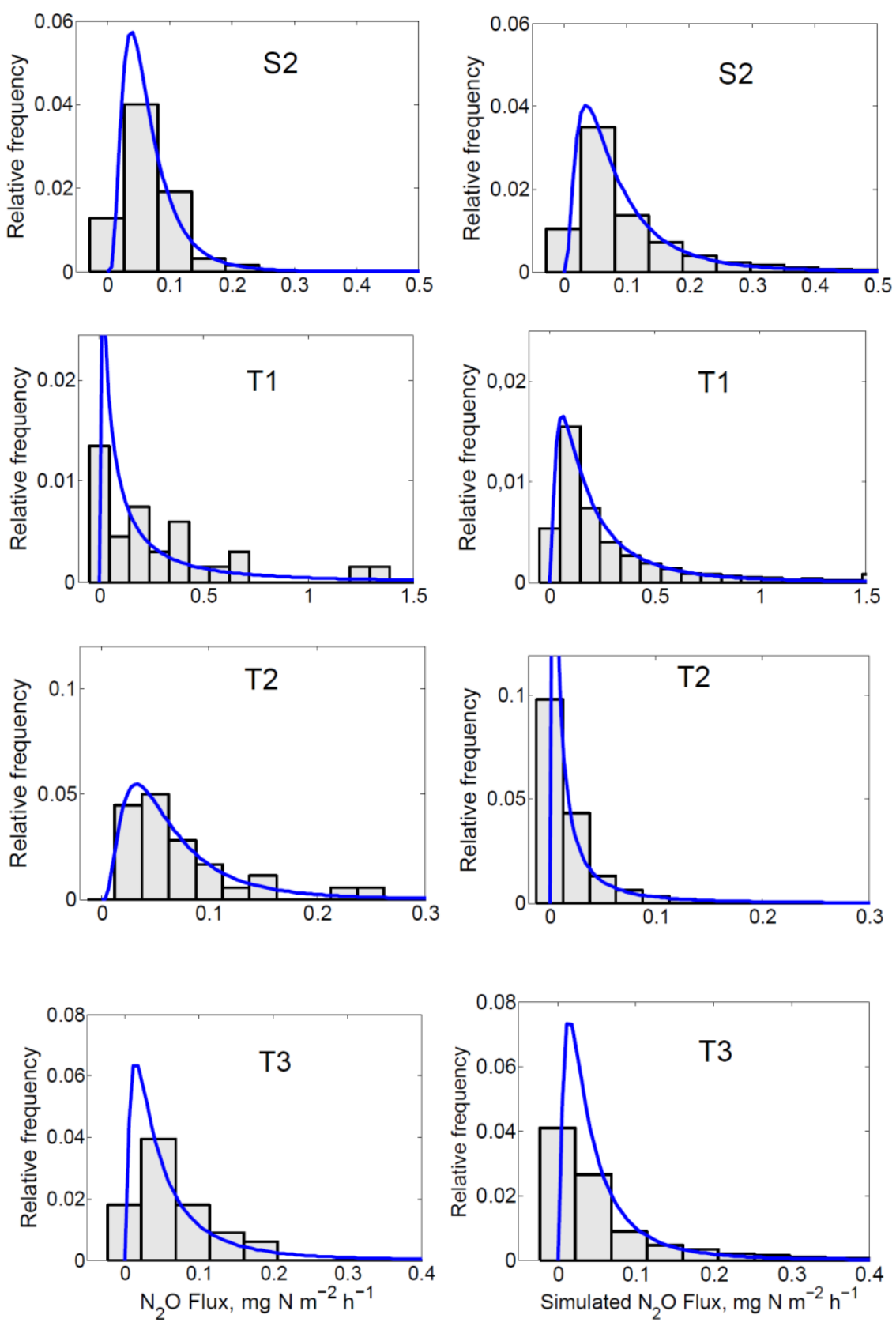

7 
a.

\begin{tabular}{lccccc}
\hline variables & $\mathbf{n}$ & mean & range & $\mathbf{C V}$ & dist \\
$\mathbf{F}\left(\mathbf{N}_{2} \mathbf{O}\right)$ & 48 & 0.413 & $0.104-1.421$ & $68 \%$ & \\
wfps & 48 & 77.1 & $72.6-87.6$ & $3 \%$ \\
$\mathrm{NO}_{3}^{-}$ & 8 & 13.8 & $7.3-21.8$ & $37 \%$ \\
$\mathbf{N H}_{4}{ }^{+}$ & 8 & 4.8 & $2.4-8.9$ & $50 \%$
\end{tabular}

S2

\begin{tabular}{c|ccc} 
distri & $\mathbf{n}$ & mean & range \\
$\mathrm{In}$ & 49 & 0.068 & $0.015-0.238$ \\
$\mathrm{n}$ & 49 & 75.9 & $71.2-82.1$ \\
$\mathrm{n}$ & 49 & 7.2 & $1.1-20.2$ \\
$\mathrm{n}$ & 49 & 9.3 & $0.7-27.5$
\end{tabular}

T2
S3

\begin{tabular}{cc|ccccc} 
CV & distri & n & mean & range & CV & distri \\
$68 \%$ & In & 49 & 0.045 & $0.000-0.125$ & $96 \%$ & In \\
$3 \%$ & $\mathrm{n}$ & 49 & 67.1 & $62.0-71.7$ & $3 \%$ & $\mathrm{x}$ \\
$44 \%$ & $\mathrm{x}$ & 49 & 14.1 & $7.3-25.8$ & $31 \%$ & $\mathrm{ln}$ \\
$70 \%$ & $\mathrm{x}$ & 49 & 10.3 & $4.7-23.1$ & $46 \%$ & $\mathrm{In}$
\end{tabular}

b.

T1

T3

\begin{tabular}{|c|c|c|c|c|c|c|c|c|c|c|c|c|c|c|c|}
\hline variables & $\mathbf{n}$ & mean & range & $\mathrm{CV}$ & distri & $n$ & mean & range & $\mathrm{CV}$ & distri & n & mean & range & CV & distri \\
\hline $\mathbf{F}\left(\mathrm{N}_{2} \mathrm{O}\right)$ & 29 & 0.354 & $0.006-1.343$ & $311 \%$ & $\ln$ & 30 & 0.071 & $0.000-0.247$ & $82 \%$ & $\ln$ & 30 & 0.073 & $0.001-0.213$ & $139 \%$ & $x$ \\
\hline $\mathrm{NO}_{3}^{-}$ & 29 & 12.7 & $7.1-21.8$ & $31 \%$ & $\ln$ & 30 & 7.4 & $4.7-14.0$ & $27 \%$ & $x$ & 30 & 17.0 & $8.7-34.7$ & $31 \%$ & $\ln$ \\
\hline
\end{tabular}

$\mathrm{NH}_{4}^{+}$

$5.8-58.8$

$39 \%$

\begin{tabular}{l|ll} 
n & 30 & 12.8
\end{tabular}

5.1-33.6

$55 \%$

In $30 \quad 25.6$

$10.2-52.0 \quad 44 \%$ 
$1 \quad$ Table 2

\begin{tabular}{lcclc} 
& n & mean & Range & CV \\
\hline Clay $<2 \mu \mathrm{m}$ & 29 & 171.8 & $145-203$ & $10 \%$ \\
fine silt 2-20 $\mu \mathrm{m}$ & 29 & 329.9 & $306-371$ & $6 \%$ \\
coarse silt 20-50 $\mu \mathrm{m}$ & 29 & 435.9 & $411-461$ & $3 \%$ \\
fine sand $50-200 \mu \mathrm{m}$ & 29 & 33.8 & $29-39$ & $7 \%$ \\
coarse sand $>200 \mu \mathrm{m}$ & 29 & 28.6 & $15-38$ & $23 \%$ \\
Organic C & 29 & 10.2 & $8.1-12.9$ & $19 \%$ \\
organic matter & 29 & 17.7 & $14.0-22.3$ & $11 \%$ \\
total N & 29 & 1.0 & $0.84-1.22$ & $9 \%$ \\
C/N ratio & 29 & 10.3 & $9.65-10.9$ & $3 \%$ \\
pH & 29 & 5.96 & $5.7-6.25$ & $2 \%$
\end{tabular}

2 
1 Table 3

\begin{tabular}{|c|c|c|c|c|}
\hline & & $r$ & $p$ & RMSE \\
\hline \multirow{6}{*}{ Per treatment } & S1 & -0.44 & 0.27 & 0.303 \\
\hline & S2 & 0.17 & 0.24 & 0.085 \\
\hline & S3 & -0.06 & 0.67 & 0.010 \\
\hline & T1 & 0.88 & $3^{e}-10$ & 0.118 \\
\hline & $\mathrm{T} 2$ & 0.06 & 0.75 & 0.068 \\
\hline & $\mathrm{T} 3$ & 0.13 & 0.50 & 0.245 \\
\hline All data & T and $S$ & 0.73 & $<0.001$ & 0.168 \\
\hline \multirow{2}{*}{$\begin{array}{l}\text { mean fluxes of } \\
\text { each campaign }\end{array}$} & determinist & 0.97 & 0.002 & 0.058 \\
\hline & stochastic & 0.98 & 0.002 & 0.033 \\
\hline
\end{tabular}

2 
1 Table 4

\begin{tabular}{lccccc} 
& \multicolumn{2}{c}{ Measured } & \multicolumn{2}{c}{ Simulated } & $\chi^{2}$ \\
\cline { 2 - 6 } & Mean & Std & Mean & Std & p-value \\
\hline S1 & $\mathbf{0 . 4 1 3}$ & $\mathbf{0 . 2 8 1}$ & $\mathbf{0 . 3 5 8}$ & $\mathbf{0 . 3 4 0}$ & $\mathbf{0 . 1 1}$ \\
S2 & $\mathbf{0 . 0 6 8}$ & $\mathbf{0 . 0 4 7}$ & $\mathbf{0 . 0 9 6}$ & $\mathbf{0 . 0 9 4}$ & $\mathbf{0 . 2 0}$ \\
S3 & 0.045 & 0.043 & - & - & - \\
T1 & $\mathbf{0 . 3 5 4}$ & $\mathbf{1 . 1 0 2}$ & $\mathbf{0 . 3 4 0}$ & $\mathbf{0 . 5 3 3}$ & $\mathbf{0 . 1 1}$ \\
T2 & 0.071 & 0.058 & 0.029 & 0.040 & $<0.0001$ \\
T3 & $\mathbf{0 . 0 7 3}$ & $\mathbf{0 . 1 0 1}$ & $\mathbf{0 . 0 6 9}$ & $\mathbf{0 . 0 9 0}$ & $\mathbf{0 . 1 7}$
\end{tabular}

2 